\title{
Carbon dioxide transport across the hillslope-riparian-stream continuum in a boreal headwater catchment
}

\author{
F. I. Leith ${ }^{1,4,5}$, K. J. Dinsmore ${ }^{1}$, M. B. Wallin ${ }^{2,5}$, M. F. Billett ${ }^{3}$, K. V. Heal ${ }^{4}$, H. Laudon ${ }^{6}$, M. G. Öquist ${ }^{6}$, and \\ K. Bishop ${ }^{5,7}$ \\ ${ }^{1}$ Centre for Ecology \& Hydrology, Edinburgh, UK \\ ${ }^{2}$ Department of Ecology and Genetics/Limnology, Uppsala University, Uppsala, Sweden \\ ${ }^{3}$ Biological and Environmental Sciences, School of Natural Sciences, University of Stirling, Stirling, UK \\ ${ }^{4}$ School of GeoSciences, University of Edinburgh, Edinburgh, UK \\ ${ }^{5}$ Department of Earth Sciences, Air Water and Landscape Sciences, Uppsala University, Uppsala, Sweden \\ ${ }^{6}$ Department of Forest Ecology and Management, Swedish University of Agricultural Sciences (SLU), Umeå, Sweden \\ ${ }^{7}$ Department of Aquatic Sciences and Assessment, Swedish University of Agricultural Sciences (SLU), Uppsala, Sweden
}

Correspondence to: F. I. Leith (f.i.leith@sms.ed.ac.uk)

Received: 29 September 2014 - Published in Biogeosciences Discuss.: 7 November 2014

Revised: 19 February 2015 - Accepted: 2 March 2015 - Published: 23 March 2015

\begin{abstract}
Headwater streams export $\mathrm{CO}_{2}$ as lateral downstream export and vertical evasion from the stream surface. $\mathrm{CO}_{2}$ in boreal headwater streams generally originates from adjacent terrestrial areas, so determining the sources and rate of $\mathrm{CO}_{2}$ transport along the hillslope-riparian-stream continuum could improve estimates of $\mathrm{CO}_{2}$ export via the aquatic pathway, especially by quantifying evasion at higher temporal resolutions. Continuous measurements of dissolved $\mathrm{CO}_{2}$ concentrations and water table were made along the hillslope-riparian-stream continuum in the Västrabäcken sub-catchment of the Krycklan catchment, Sweden. Daily water and $\mathrm{CO}_{2}$ export from the hillslope and riparian zone were estimated over one hydrological year (October 2012September 2013) using a flow-concentration model and compared with measured lateral downstream $\mathrm{CO}_{2}$ export.

Total water export over the hydrological year from the hillslope was $230 \mathrm{mmyr}^{-1}$ compared with $270 \mathrm{mmyr}^{-1}$ from the riparian zone. This corresponds well (proportional to the relative upslope contributing area) to the annual catchment runoff of $265 \mathrm{~mm} \mathrm{yr}^{-1}$. Total $\mathrm{CO}_{2}$ export from the riparian zone to the stream was $3.0 \mathrm{~g} \mathrm{CO}_{2}-\mathrm{C} \mathrm{m}^{-2} \mathrm{yr}^{-1}$. A hotspot for riparian $\mathrm{CO}_{2}$ export was observed at $30-50 \mathrm{~cm}$ depth (accounting for $71 \%$ of total riparian export). Seasonal variability was high with export peaks during the spring flood and autumn storm events. Downstream lateral $\mathrm{CO}_{2}$ export (determined from stream water dissolved $\mathrm{CO}_{2}$ concentra-
\end{abstract}

tions and discharge) was $1.2 \mathrm{~g} \mathrm{CO}_{2}-\mathrm{C} \mathrm{m}^{-2} \mathrm{yr}^{-1}$. Subtracting downstream lateral export from riparian export $\left(3.0 \mathrm{~g} \mathrm{CO}_{2}\right.$ $\mathrm{C} \mathrm{m}^{-2} \mathrm{yr}^{-1}$ ) gives $1.8 \mathrm{~g} \mathrm{CO}_{2}-\mathrm{C} \mathrm{m}^{-2} \mathrm{yr}^{-1}$ which can be attributed to evasion losses (accounting for $60 \%$ of export via the aquatic pathway). The results highlight the importance of terrestrial $\mathrm{CO}_{2}$ export, especially from the riparian zone, for determining catchment aquatic $\mathrm{CO}_{2}$ losses and the importance of the $\mathrm{CO}_{2}$ evasion component to carbon export via the aquatic conduit.

\section{Introduction}

Boreal forests are an important ecosystem within high latitude regions containing a globally significant carbon store in both soils and vegetation (Dunn et al., 2007; Pregitzer and Euskirchen, 2004). The net ecosystem carbon balance (NECB) of individual northern latitude catchments has shown them to be net sinks for carbon (Dinsmore et al., 2010, 2013b; Koehler et al., 2011; Nilsson et al., 2008; Olefeldt et al., 2012; Roulet et al., 2007). In boreal forest catchments, carbon export via the aquatic pathway (consisting of dissolved organic carbon (DOC), dissolved inorganic carbon (DIC), particulate organic carbon (POC) plus dissolved and gaseous $\mathrm{CO}_{2}$ and $\mathrm{CH}_{4}$ ) accounted for 4-28\% of carbon uptake via net ecosystem exchange (NEE), representing an im- 
portant, but spatially and temporally variable component of the NECB (Öquist et al., 2014; Wallin et al., 2013).

Headwater streams are generally supersaturated in $\mathrm{CO}_{2}$ with respect to the atmosphere, resulting in export via the aquatic conduit consisting of both the downstream lateral export and vertical evasion of $\mathrm{CO}_{2}$ from the stream surface (Kling et al., 1991). $\mathrm{CO}_{2}$ evasion has been shown to account for $13-53 \%$ of the total aquatic flux across a range of northern latitude headwater streams (Billett et al., 2004; Öquist et al., 2009; Wallin et al., 2013), representing an important component of the catchment NECB. Low order streams have been observed to have disproportionately high evasion rates (Aufdenkampe et al., 2011; Butman and Raymond, 2011; Raymond et al., 2013). Across Sweden, $\mathrm{CO}_{2}$ evasion from first order streams was estimated at $0.205 \mathrm{Tg} \mathrm{C} \mathrm{yr}^{-1}$ or $39 \%$ of the total from all streams, despite accounting for only $13 \%$ of the total stream area (Humborg et al., 2010). Quantifying evasion involves combining dissolved $\mathrm{CO}_{2}$ concentrations and the gas transfer coefficient $\left(\mathrm{KCO}_{2}\right)$ (Hope et al., 2001). Due to the limited numbers of direct measurements of the gas transfer coefficient $\left(K \mathrm{CO}_{2}\right)$ (Raymond et al., 2013; Wallin et al., 2011) and the considerable spatial (Wallin et al., 2014) and temporal (Crawford et al., 2013; Dinsmore et al., 2013a) variability in dissolved $\mathrm{CO}_{2}$ concentrations observed across a wide range of northern latitude catchments, evasion, and the drivers of this flux are likely to be poorly quantified. To improve understanding of both lateral downstream export and vertical evasion of $\mathrm{CO}_{2}$ from headwater streams the concentrations and sources of dissolved $\mathrm{CO}_{2}$ need to be better quantified.

To better understand the drivers of stream water $\mathrm{CO}_{2}$ dynamics an increasing number of studies have made continuous, direct measurements of dissolved $\mathrm{CO}_{2}$ concentrations in stream waters (using in situ, non-dispersive infra-red (NDIR) $\mathrm{CO}_{2}$ sensors) giving new insights into diurnal, storm event and seasonal $\mathrm{CO}_{2}$ dynamics (Dinsmore and Billett, 2008; Dinsmore et al., 2013a; Dyson et al., 2011; Johnson et al., 2006, 2010). Much of the excess $\mathrm{CO}_{2}$ in temperate and boreal streams originates from terrestrial areas through lateral subsurface transport through the soil (Hope et al., 2004), confirmed by isotope studies in peatland catchments (Garnett et al., 2012; Leith et al., 2014). The concentration of $\mathrm{CO}_{2}$ in stream water is largely dependent on the concentration in terrestrial source areas and the hydrological connectivity between source areas and the stream channel (Vidon et al., 2010). Despite the apparent importance of soil sources, most studies of stream $\mathrm{CO}_{2}$ dynamics take the observed response in the stream and link it to terrestrial processes without direct measurements in soils. Quantifying the rate of export of carbon from soil to stream will enable better estimates of $\mathrm{CO}_{2}$ export via the aquatic pathway and in particular contribute to higher temporal resolution estimates of evasion.

A few studies have made continuous, high frequency $\mathrm{CO}_{2}$ concentration measurements in soils but are largely restricted to sampling at shallow depths above the water table (Dins- more et al., 2009; Jassal et al., 2004, 2008; Tang et al., 2003). Higher soil $\mathrm{CO}_{2}$ concentrations have been observed below the water table and in response to soil re-wetting after storms (Jassal et al., 2005; Rasilo et al., 2012). In soil, $\mathrm{CO}_{2}$ can be derived from root respiration, soil organic matter decomposition and weathering of carbonate parent material. Mobilisation of $\mathrm{CO}_{2}$ occurs through the displacement of high $\mathrm{CO}_{2}$ concentrations in the soil atmosphere, combined with decreased vertical diffusivity as soil pore space becomes saturated $\left(\mathrm{CO}_{2}\right.$ diffusion is 10000 times slower in water than in air) (Šimůnek and Suarez, 1993). This highlights the importance of considering concentration changes over the full soil profile depth, especially in horizons which experience frequent water table fluctuations as transient saturation can increase the lateral export of water and dissolved constituents exponentially (Bishop et al., 2011).

The terrestrial-aquatic interface is a continuum between the wider catchment area (hillslope), riparian zone and stream. Riparian zones in headwater catchments commonly represent a $1-5 \mathrm{~m}$ wide area immediately adjacent to the stream (Luke et al., 2007). Common characteristics of the riparian zone are higher water table conditions (Burt et al., 2002), organic rich soils and distinct vegetation composition in comparison to the surrounding hillslope (Lyon et al., 2011). Hence, the riparian zone has been widely shown to be a key area for hydrological, ecological and biochemical processes (Naiman and Décamps, 1997; Vidon et al., 2010). Subsurface hydrological flow paths converge at the terrestrial-aquatic interface resulting in the riparian zone being the last biogeochemical environment encountered by subsurface water (Bishop et al., 1990; McClain et al., 2003). The riparian zone has been shown to have a stronger hydrological connection to the stream in comparison to groundwater or soil water (Buttle et al., 2004; Stieglitz et al., 2003) and to control stream water chemistry during hydrological events (Bishop et al., 2004). Water and solute transport has been shown to be episodic with hotspots and hot moments in export (McClain et al., 2003; Vidon et al., 2010), hence the full hillslope-riparian-stream continuum needs to be considered at high temporal resolutions to quantify solute transport across the terrestrial-aquatic interface.

Across five different northern latitude catchments, stream water $\mathrm{CO}_{2}$ concentrations were shown to be strongly linked to discharge, with the highest $30 \%$ of flow having the greatest impact on lateral $\mathrm{CO}_{2}$ export (Dinsmore et al., 2013a). DIC export via the aquatic pathway over a 13-year period in a headwater Swedish catchment (the same catchment as this study) was positively correlated with precipitation with export varying from 2.3 to $6.9 \mathrm{~g}$ DIC-C m${ }^{-2} \mathrm{yr}^{-1}$ (Öquist et al., 2014). In boreal systems, water and carbon cycles are highly seasonal and strongly linked to the length of the snow covered period in winter and the spring snow melt event. In these systems, snowmelt is the major hydrological event of the year, with one example being the Krycklan catchment where $40-60 \%$ of the annual runoff occurs during only $10-15 \%$ 
of the year (Laudon et al., 2011). Snowmelt has been shown to be an important period for carbon export via the aquatic pathway both as DOC (Laudon et al., 2004; Nilsson et al., 2008) and gaseous species (Dyson et al., 2011). Another example of the short-term variability in stream water dissolved $\mathrm{CO}_{2}$ concentrations is the observation in some catchments of bimodal frequency distributions during storms, indicative of two distinct $\mathrm{CO}_{2}$ sources within the catchment (Dinsmore et al., 2013a). Combining high resolution concentration measurements in both the soil and the stream is a powerful way of studying hydrological and seasonal variability in these catchments. However, previous studies which determined dissolved $\mathrm{CO}_{2}$ concentrations in riparian soils and streams have used either a limited number of discrete measurements (Hope et al., 2004; Öquist et al., 2009) or did not determine the variability in the depth of lateral subsurface hydrological flow paths transporting $\mathrm{CO}_{2}$ to the stream (Rasilo et al., 2012). This is likely to under represent variability in these dynamic systems, especially for short lived hydrological events such as storms.

This study uses high temporal resolution measurements of $\mathrm{CO}_{2}$ concentrations along a hillslope-riparian-stream continuum in a hydrologically well defined catchment with extensive previous work delineating the hydrological flow paths along the continuum (Bishop et al., 2004; Seibert et al., 2009; Stähli et al., 2001). This allows the sources of stream water $\mathrm{CO}_{2}$ to be investigated while estimating the export of water and $\mathrm{CO}_{2}$ across the terrestrial-aquatic interface. Due to the position of riparian zones within the catchment and the greater potential for $\mathrm{CO}_{2}$ production in the organic rich riparian soils we hypothesise that it is the riparian zone, rather than the wider catchment area, that is maintaining $\mathrm{CO}_{2} \mathrm{ex}-$ port to streams.

\section{Materials and methods}

\subsection{Site description}

This study was conducted in the $0.13 \mathrm{~km}^{2}$ forested Västrabäcken subcatchment of the $0.47 \mathrm{~km}^{2}$ Svartberget catchment, which is part of the wider $68 \mathrm{~km}^{2}$ Krycklan catchment $\left(64^{\circ} 14^{\prime} \mathrm{N}, 19^{\circ} 46^{\prime} \mathrm{E}\right), 50 \mathrm{~km}$ north-west of Umeå, Sweden (Laudon et al., 2013).

The altitude of the catchment ranges from 235 to 310 ma.s.l. (Bishop et al., 1990). Mean annual temperature (1980-2008) is $1.7^{\circ} \mathrm{C}$, with the maximum $\left(14.6^{\circ} \mathrm{C}\right)$ and minimum $\left(-9.6^{\circ} \mathrm{C}\right)$ in July and January, respectively. Mean annual precipitation (1981-2008) is $612 \mathrm{~mm}$, with approximately $35 \%$ falling as snow (Haei et al., 2010). Snow covers the ground on average for 171 days from October to May to a depth of between 43 and $113 \mathrm{~cm}$ (1980-2007) (Laudon et al., 2011). The largest hydrological event during the year is a 46 week long snowmelt period in late April/early May which contributes between 40 and $60 \%$ of annual runoff (Laudon et al., 2011). The Västrabäcken is a first order, low pH (range $\mathrm{pH}$ 4.5-5.9) with little variability in the bicarbonate equilibrium system (Wallin et al., 2010).

Drainage channels were deepened and widened in the 1920s to improve forest drainage (Bishop et al., 1990). Scots pine (Pinus sylvestris) is the dominant tree species in hillslope areas with some Norway spruce (Picea abies) nearer to the stream. Understorey vegetation is predominately a mix of Vaccinium myrtillus, Vaccinium vitis-idaea and grasses (Deschampsia flexuosa), with mosses (Sphagnum spp., Polytrichum commune) and wood horsetail (Equisetum sylvaticum) in the wetter riparian areas.

The bedrock is gneiss overlain by $10-15 \mathrm{~m}$ of locally derived glacial till. Soils consist of well-developed iron podzols comprising a surface $5 \mathrm{~cm}$ humus layer overlying a $12 \mathrm{~cm}$ thick sandy bleached E-horizon and a $60 \mathrm{~cm}$ thick B-horizon (Nyberg et al., 2001). The riparian zone formed through the accumulation of organic matter in low lying areas and extends $4 \mathrm{~m}$ on either side of the stream channel. Riparian soils consist of $\sim 70 \mathrm{~cm}$ thick peat transitioning to the underlying till at $\sim 90 \mathrm{~cm}$ depth. Soil organic content is considerably higher in the riparian soil $(>80 \%)$ compared to the hillslope podzols $(<5 \%)$ (Nyberg et al., 2001). Saturated hydraulic conductivity is about one order of magnitude lower in the riparian zone $\left(6.2 \times 10^{-6} \mathrm{~m} \mathrm{~s}^{-1}\right)$ than the hillslope $\left(5.6 \times 10^{-5} \mathrm{~m} \mathrm{~s}^{-1}\right)$ (Nyberg et al., 2001) decreasing with depth (Stähli et al., 2001). Porosity and water retention were higher in the riparian soil (Nyberg et al., 2001; Stähli et al., 2001). The riparian zone studied is representative of headwater till catchments across the larger Krycklan catchment (Grabs et al., 2012).

\subsection{Field methods}

Sampling was carried out in both the hillslope podzol soils ( $15 \mathrm{~m}$ perpendicular to the stream) and riparian zone peat soils (1.5 m from the stream) (Fig. 1). At each location, two dipwells with a $10 \mathrm{~cm}$ perforated sampling window at either $30-40$ or $60-70 \mathrm{~cm}$ depth were installed, with the dipwells separating the soil water from the surrounding soil allowing the measurement of soil water $\mathrm{CO}_{2}$ concentrations. Dipwells were constructed from $50 \mathrm{~mm}$ inner diameter (ID) pipe open at the bottom and sealed at the surface using rubber bungs (Saint Gobain Performance Plastics, France). To prevent damage to the dipwells over winter due to freezing, the short above ground section was covered in insulation foam. Each dipwell contained a Vaisala CARBOCAP GMP221 non-dispersive infra-red (NDIR) $\mathrm{CO}_{2}$ sensor (range 0-5\%). Prior to deployment, sensors were enclosed in a water-tight, gas-permeable membrane (Johnson et al., 2006, 2010). At each sampling point a third dipwell, constructed from $90 \mathrm{~mm}$ ID pipe perforated along its entire $1 \mathrm{~m}$ length and open at the bottom, was used for the measurement of water table depth (Level Troll 300, In-situ, USA) and soil temperature (CS457A, Campbell Scientific, USA), with sensors sus- 


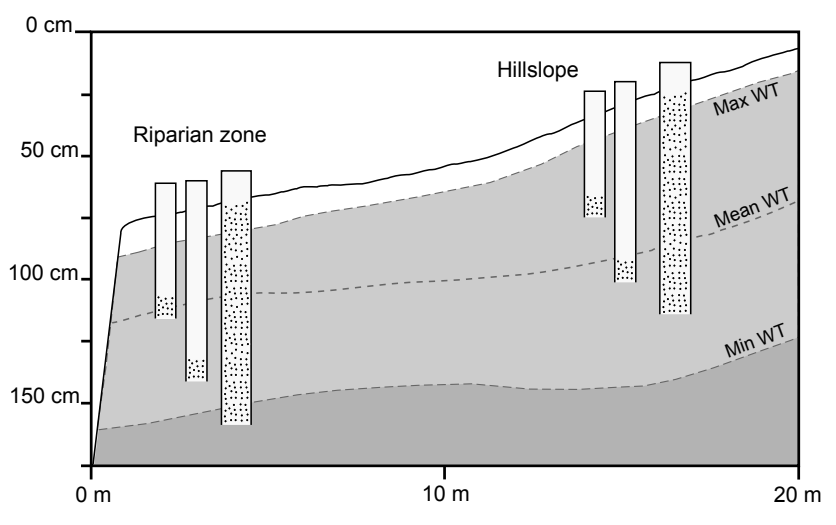

Figure 1. Schematic of the hillslope-riparian transect used in this study. $\mathrm{CO}_{2}$ sensors were installed in dipwells with sampling windows at 30-40 and 60-70 cm depth. An additional dipwell for water table and soil temperature was perforated along the full length to $90 \mathrm{~cm}$ depth. The grey box indicates the zone of transient saturation (between max and min water table positions) over the hydrological year.

pended at $90 \mathrm{~cm}$ depth. All sensors were connected to a data logger (CR1000, Campbell Scientific, USA) which recorded measurements at $30 \mathrm{~min}$ intervals. The system ran for three months (from 1 July 2012) to allow it to become stabilised and equilibrated before the main measurement period over one hydrological year (1 October 2012-30 September 2013). Soil moisture content was recorded by time domain reflectometry (TDR) probes (Laudon et al., 2013; Nyberg et al., 2001).

Measurements were made at one point in the hillslope and riparian zone assuming, as with all transect studies, that these points are representative of the catchment overall. A single transect approach is appropriate for this catchment due to the small area $\left(0.13 \mathrm{~km}^{2}\right)$ and limited variability in soils and vegetation (Bishop et al., 1990; Lyon et al., 2011). Furthermore, overland flow or deeper groundwater inputs to the stream have been shown to be limited in this catchment (Laudon et al., 2004; Peralta-Tapia et al., 2014). The sampled riparian zone is consistent with the 13 riparian zones in the wider Krycklan Riparian Observatory (Grabs et al., 2012).

Stream water dissolved $\mathrm{CO}_{2}$ concentrations (measured using the same Vaisala $\mathrm{CO}_{2}$ sensors), plus discharge were measured continuously in a heated dam house at the catchment outlet (Laudon et al., 2013), $200 \mathrm{~m}$ downstream from and over the same time period as soil measurements.

\subsection{Data processing and analysis}

$\mathrm{CO}_{2}$ sensor output was corrected for temperature and pressure using the method of Tang et al. (2003) but using algorithms supplied by the manufacturer specific to the GMP221 sensors. In addition to atmospheric pressure, the correction also accounted for the head of water above the sensor, related to the water table depth at the time of sampling. Corrected concentrations are given in units of ppmv with $\mathrm{mgCO}_{2}$ $\mathrm{CL}^{-1}$ used for export calculations.

The export of water and $\mathrm{CO}_{2}$ from each $\mathrm{m}^{2}$ of hillslope and riparian zone were estimated using a flow-concentration model, a similar approach to the riparian integration model concept used previously in this, and similar, hillsloperiparian systems (Grabs et al., 2012; Seibert et al., 2009). Our study used measured water table positions in the hillslope and riparian zone while previous studies have used a correlation between groundwater and runoff dynamics (Grabs et al., 2012).

The model was constructed by subdividing the $90 \mathrm{~cm}$ deep soil profile into $5 \mathrm{~cm}$ horizons. The daily lateral water export from each $5 \mathrm{~cm}$ soil layer was estimated by combining the measured volumetric water content with lateral saturated hydraulic conductivity estimated by Stähli et al. (2001). Total daily water export from the full soil profile was estimated by adding together the lateral flow from all $5 \mathrm{~cm}$ horizons below the daily mean water table. As $\mathrm{CO}_{2}$ concentration was only measured at two depths (30-40 and 60-70 cm) these were assumed to represent the concentration above and below $45 \mathrm{~cm}$ depth. Daily average $\mathrm{CO}_{2}$ concentrations below the water table, in $\mathrm{mg} \mathrm{CO}_{2}-\mathrm{CL}^{-1}$, were multiplied by the water export, with $\mathrm{CO}_{2}$ export expressed in units of $\mathrm{mg} \mathrm{CO}_{2}-\mathrm{C} \mathrm{m}^{-2}$ day $^{-1}$. The model was run twice to estimate the export from (1) podzol hillslope soils and (2) riparian organic soils. Hillslope export was taken to represent the input of water and $\mathrm{CO}_{2}$ into the riparian zone with riparian export representing the total terrestrial water and $\mathrm{CO}_{2}$ export to the stream.

Downstream $\mathrm{CO}_{2}$ export was determined by multiplying daily mean stream water $\mathrm{CO}_{2}$ concentration with discharge at the catchment outlet. Based on the assumption that all stream water carbon is derived from terrestrial inputs, evasion was estimated by subtracting the downstream lateral $\mathrm{CO}_{2}$ export from the export of $\mathrm{CO}_{2}$ from the riparian zone to the stream. Whilst we recognise this assumption may not be completely met and we may be underestimating total inputs and therefore evasion, in stream processing in this catchment is likely to be minimal due to the low temperatures, $\mathrm{pH}$ and short water residence time (Öquist et al., 2009). Our results therefore provide a useful means to consider temporal variability in a flux which is otherwise unmeasurable at high temporal resolution.

\section{Results}

\subsection{Hillslope-riparian hydrological connectivity}

Water table was significantly higher in the riparian zone compared to the hillslope, but with similar temporal variability (Fig. 2). Mean ( $\pm \mathrm{SD}$ ) hillslope water table during the hydrological year was $-63 \pm 16 \mathrm{~cm}$ compared with $-37 \pm 10 \mathrm{~cm}$ in the riparian zone (Table 1). Volumetric soil moisture content was also higher in the riparian zone (mean $\pm \mathrm{SD}$ 
Table 1. Mean (min-max) calculated from all continuous measurements over the hydrological year (1 October 2012-30 September $2013)$ in the hillslope and riparian zone. Significant differences between the hillslope and riparian zone sampling points (at $P<0.01$ ) are indicated by $* *$.

\begin{tabular}{lrr}
\hline & Hillslope & Riparian \\
\hline Water table depth $(\mathrm{cm})^{* *}$ & -63 & -37 \\
& $(-118$ to -10$)$ & $(-83$ to -12$)$ \\
\hline Temperature $\left({ }^{\circ} \mathrm{C}\right)^{* *}$ & 4.1 & 3.9 \\
& $(0.8-9.2)$ & $(0.6-9.2)$ \\
\hline $\mathrm{CO}_{2}$ (ppmv) 30-40 cm** & 4410 & 15130 \\
& $(1680-11730)$ & $(4430-21730)$ \\
\hline $\mathrm{CO}_{2}$ (ppmv) 60-70 cm** & 5790 & 23100 \\
& $(1170-15770)$ & $(16140-31920)$ \\
\hline
\end{tabular}
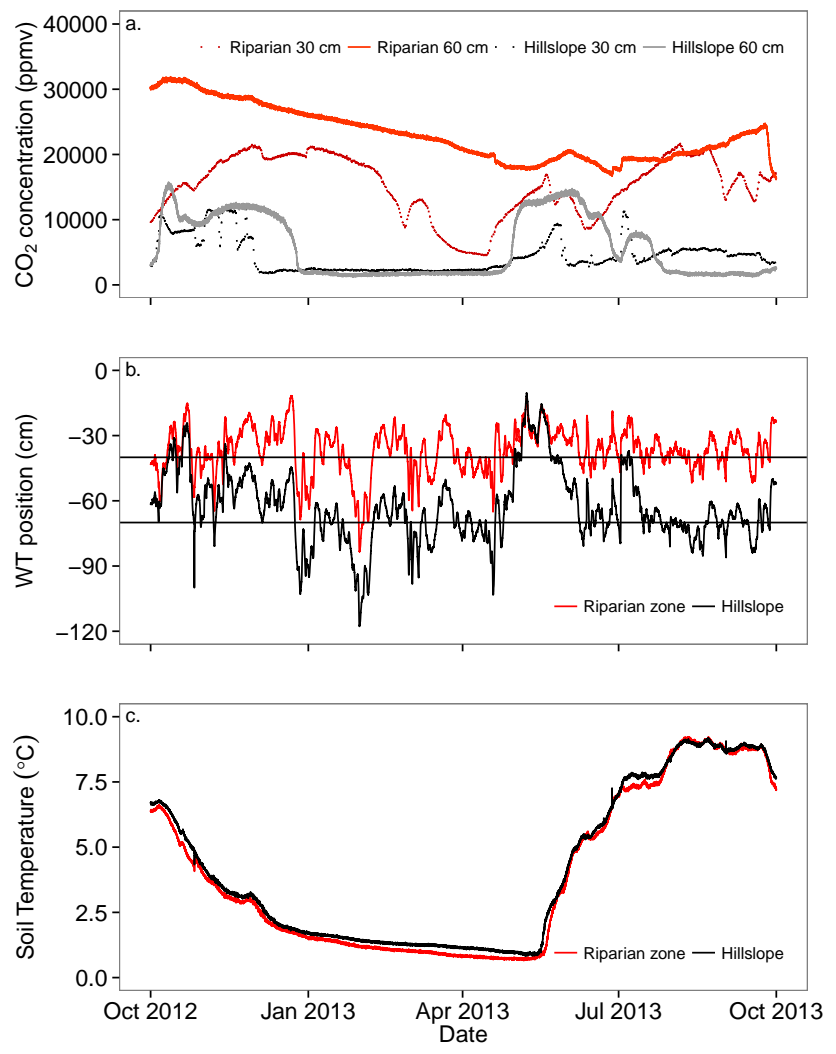

Figure 2. Time series of hillslope and riparian zone (a) $\mathrm{CO}_{2}$ concentrations sampled at 30-40 and 60-70 cm depths, (b) water table and (c) soil temperature across the full measurement period. Horizontal lines in (b) highlight the deepest depths sampled by the 30 40 and $60-70 \mathrm{~cm}$ depth $\mathrm{CO}_{2}$ sensors.

of $0.73 \pm 0.008$ and $0.46 \pm 0.004 \mathrm{~m}^{3} \mathrm{~m}^{-3}$ at 30 and $60 \mathrm{~cm}$ depths, respectively) compared to the hillslope $(0.50 \pm 0.01$ and $0.45 \pm 0.003 \mathrm{~m}^{3} \mathrm{~m}^{-3}$ at 30 and $60 \mathrm{~cm}$ depths, respectively).
Annual mean $( \pm \mathrm{SD})$ soil temperature was $4.1 \pm 3.0$ and $3.9 \pm 3.0^{\circ} \mathrm{C}$ in the hillslope and riparian zone respectively with a strong seasonal trend (Fig. 2). Soil temperature (measured at $70 \mathrm{~cm}$ depth) did not fall below freezing, with minimum temperatures in the hillslope $\left(0.8^{\circ} \mathrm{C}\right)$ and riparian $\left(0.7^{\circ} \mathrm{C}\right)$ (Table 1) reached at the beginning of May (Fig. 2).

Water table was above the $60 \mathrm{~cm} \mathrm{CO}_{2}$ measurement depth for 32 and $97 \%$ of the time and above the $30 \mathrm{~cm}$ depth 7 and $59 \%$ of the time, in the hillslope and riparian zone, respectively. These values describe the relative proportion of the measurement period over which the $\mathrm{CO}_{2}$ sensors were submerged.

\subsection{Hillslope-riparian $\mathrm{CO}_{2}$ concentrations}

$\mathrm{CO}_{2}$ concentrations were on average higher in the riparian zone than the corresponding depth in the hillslope (Table 1). The highest mean $( \pm \mathrm{SD}) \mathrm{CO}_{2}$ concentrations were at 60 $70 \mathrm{~cm}$ in the riparian zone $(23100 \pm 4100 \mathrm{ppmv})$ with the lowest at $30-40 \mathrm{~cm}$ in the hillslope $(4410 \pm 2570 \mathrm{ppmv})$. At both depths the hillslope and riparian zone $\mathrm{CO}_{2}$ concentrations were significantly different (Table 1).

There was considerable temporal variability in $\mathrm{CO}_{2}$ concentration in the hillslope, which displayed a baseline and peak pattern (Fig. 2). Baseline concentrations were generally $<2000 \mathrm{ppmv}$. In the winter period (January-March), median concentrations at $60-70 \mathrm{~cm}$ depth $(1600 \mathrm{ppmv})$ were $24 \%$ less than those at $30-40 \mathrm{~cm}$ depth $(2110 \mathrm{ppmv})$. During drier periods in summer (July-September), the baseline was higher with median concentrations at $60-70 \mathrm{~cm}$ (1770 ppmv), $61 \%$ less than those at $30-40 \mathrm{~cm}$ depth (4530 ppmv). The range was also higher in summer (7640 and $6470 \mathrm{ppmv}$ at $30-40$ and $60-70 \mathrm{~cm}$ depths) than in winter (680 and $870 \mathrm{ppmv})$.

Periodically, sharp increases in hillslope $\mathrm{CO}_{2}$ concentrations were observed, corresponding to a rise in water table position (Fig. 2). $\mathrm{CO}_{2}$ concentrations in the hillslope had a positive correlation with hillslope water table at 30$40 \mathrm{~cm}\left(\left(r^{2}=0.43 ; P<0.001\right)\right.$ and $60-70 \mathrm{~cm}\left(r^{2}=0.65\right.$; $P<0.001)$ depths. Over the measurement period the two spikes with the highest $\mathrm{CO}_{2}$ concentrations (14100 and $13160 \mathrm{ppmv}$ ) occurred when the water table was above the level of the deeper $(60-70 \mathrm{~cm}$ depth) sensor at -41 and $-51 \mathrm{~cm}$, respectively.

$\mathrm{CO}_{2}$ concentrations in the riparian zone did not display the same baseline and peak pattern as the hillslope. At 60$70 \mathrm{~cm}$ depth, $\mathrm{CO}_{2}$ concentrations peaked at $31920 \mathrm{ppmv}$ in October before falling to $16140 \mathrm{ppmv}$ in April (Fig. 2). This change in concentration closely followed soil temperature which decreased over a similar period from $9.2^{\circ} \mathrm{C}$ to the annual minimum of $0.7^{\circ} \mathrm{C}$ on 26 April 2013 (Fig. 2), coinciding with minimum $\mathrm{CO}_{2}$ concentrations. $\mathrm{CO}_{2}$ concentrations had a weak positive correlation with riparian water table at $30-40 \mathrm{~cm}\left(r^{2}=0.12 ; P<0.001\right)$ and a weak negative correlation at $60-70 \mathrm{~cm}\left(r^{2}=-0.21 ; P<0.001\right)$ depth. At $30-$ 


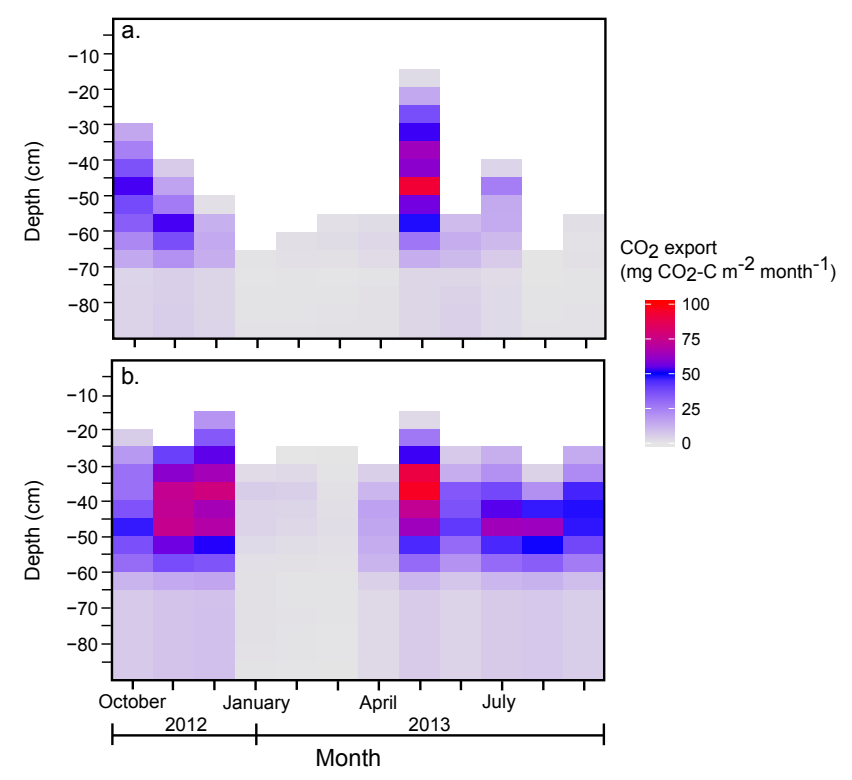

Figure 3. Total monthly export of $\mathrm{CO}_{2}$ from the (a) hillslope and (b) riparian zone across the measurement period.

$40 \mathrm{~cm}$ depth in the riparian) depth. At $30-40 \mathrm{~cm}$ depth in the riparian zone there was considerably more temporal variability in $\mathrm{CO}_{2}$ concentrations than at $60-70 \mathrm{~cm}$ depth with concentrations at $30-40 \mathrm{~cm}$ depth rising during periods of higher water table. Minimum concentrations (4430 ppmv) occurred in April before the spring snowmelt event.

\subsection{Hillslope-riparian water and $\mathrm{CO}_{2}$ export}

Annual water export from each $\mathrm{m}^{2}$ of hillslope over the hydrological year was estimated at $230 \mathrm{~mm} \mathrm{yr}^{-1}$. Across the year, water export was consistently low with flow largely restricted to below $\sim 50 \mathrm{~cm}$ depth. Total monthly export was highest in May $\left(109 \mathrm{~mm} \mathrm{month}^{-1}\right)$ accounting for $47 \%$ of the annual hillslope water export, due to greater flow at 25$35 \mathrm{~cm}$ depth $\left(37 \mathrm{~mm} m o n t h^{-1}\right)$. Hillslope $\mathrm{CO}_{2}$ export over the hydrological year was $1144 \mathrm{mg} \mathrm{CO}_{2}-\mathrm{C} \mathrm{m}^{-2} \mathrm{yr}^{-1}$ and followed a similar pattern to water export. $\mathrm{CO}_{2}$ export was considerably higher in May $\left(482 \mathrm{mg} \mathrm{CO}_{2}-\mathrm{C} \mathrm{m}^{-2}\right.$ month $\left.^{-1}\right)$, accounting for $42 \%$ of the annual $\mathrm{CO}_{2}$ export, largely due to considerable export $\left(93 \mathrm{mg} \mathrm{CO}_{2}-\mathrm{C} \mathrm{m}^{-2} \mathrm{month}^{-1}\right)$ from $45-$ $50 \mathrm{~cm}$ depth (Fig. 3).

\subsection{Riparian-stream water and $\mathrm{CO}_{2}$ export}

Annual water export from the riparian zone to the stream channel over the hydrological year was estimated at $270 \mathrm{~mm} \mathrm{yr}^{-1}$. Below $65 \mathrm{~cm}$ depth, although water export was relatively low $\left(<3 \mathrm{~mm} \mathrm{month}^{-1}\right)$ it occurred for $>97 \%$ of the measurement period. Water export was highest in a zone between 25 and $50 \mathrm{~cm}$ depth. At shallower depths $(0-25 \mathrm{~cm})$ flow was restricted to the wettest months. Total monthly export was highest in May ( $49 \mathrm{~mm} \mathrm{month}^{-1}$ ) due to dominant flow at $25-50 \mathrm{~cm}$ depth with maximum monthly flow $\left(9 \mathrm{~mm} \mathrm{month}^{-1}\right)$ at $35-40 \mathrm{~cm}$ depth.

Total annual $\mathrm{CO}_{2}$ export from the riparian zone to the stream channel over the hydrological year was estimated at $3008 \mathrm{mg} \mathrm{CO}_{2}-\mathrm{C} \mathrm{m}^{-2} \mathrm{yr}^{-1}$. Two monthly peaks in riparian $\mathrm{CO}_{2}$ export to the stream occurred over the hydrological year, in December $\left(529 \mathrm{mg} \mathrm{CO}_{2}-\mathrm{C} \mathrm{m}^{-2} \mathrm{month}^{-1}\right)$ and May (522 mg CO $2-\mathrm{C} \mathrm{m}^{-2}$ month $^{-1}$ ). $\mathrm{CO}_{2}$ export was highest in a narrow zone between 25 and $50 \mathrm{~cm}$ depth (Fig. 3). In December, water flow $\left(5 \mathrm{~mm} \mathrm{month}^{-1}\right)$ and $\mathrm{CO}_{2}$ export $\left(77 \mathrm{mg} \mathrm{CO}_{2}-\mathrm{C} \mathrm{m}^{-2} \mathrm{month}^{-1}\right.$ ) were highest from $35-40 \mathrm{~cm}$ depth. In May, maximum flow of both water and $\mathrm{CO}_{2}$ was from the same depth $(35-40 \mathrm{~cm})$ at $9 \mathrm{~mm} \mathrm{month}^{-1}$ and $96 \mathrm{mg} \mathrm{CO}_{2}-\mathrm{C} \mathrm{m}^{-2}$ month $^{-1}$.

\subsection{Downstream $\mathrm{CO}_{2}$ export and evasion}

Total catchment runoff over the hydrological year was $265 \mathrm{~mm} \mathrm{yr}^{-1}$ (Fig. 4). Total downstream lateral $\mathrm{CO}_{2} \mathrm{ex}-$ port from the catchment was estimated at $1183 \mathrm{mg} \mathrm{CO}_{2}-$ $\mathrm{C} \mathrm{m}^{-2} \mathrm{yr}^{-1}$. There was considerable temporal variability in the downstream lateral export of $\mathrm{CO}_{2}$ from the catchment, related to temporal variability in discharge (Fig. 4). Median downstream lateral export was $1.2 \mathrm{mg} \mathrm{CO}_{2}-\mathrm{Cm}^{-2} \mathrm{day}^{-1}$ with two large spikes (57 and $35 \mathrm{mg} \mathrm{CO}_{2}-\mathrm{C} \mathrm{m}^{-2} \mathrm{day}^{-1}$ ) corresponding to sudden increases in discharge after storm events. Over the same period the input of $\mathrm{CO}_{2}$ from the soil to the stream was $3008 \mathrm{mg} \mathrm{CO}_{2}-\mathrm{C} \mathrm{m}^{-2} \mathrm{yr}^{-1}$. Based on the assumption that all stream water $\mathrm{CO}_{2}$ is derived from soil input then by subtraction $1825 \mathrm{mgCO}_{2}-\mathrm{C} \mathrm{m}^{-2} \mathrm{yr}^{-1}$ is lost between the soil and the stream (i.e. evasion from the stream surface), which accounted for $60 \%$ of export via the aquatic pathway (Fig. 4).

\section{Discussion}

\subsection{Hillslope-riparian $\mathrm{CO}_{2}$ concentrations}

It was hypothesised that $\mathrm{CO}_{2}$ concentrations would be higher in the riparian zone as a result of enhanced production (by decomposition of soil organic matter and root respiration) due to the higher organic matter content of riparian peat (> 80\%) compared to hillslope podzols $(<5 \%)$ (Nyberg et al., 2001) and greater mobilisation of $\mathrm{CO}_{2}$ due to the generally wetter conditions found in riparian zones (Burt et al., 2002). Changes in the soil water content can result in: (1) initial displacement of high $\mathrm{CO}_{2}$ concentration soil atmosphere as soils become saturated and (2) decreased vertical diffusion as soil pore space becomes saturated with water. Weathering of carbonate parent material can also contribute but carbonate bedrock is not found in this catchment (Wallin et al., 2013). Mean hillslope concentrations (Table 1) are within the range $(\sim 400$ to $\sim 10000 \mathrm{ppmv})$ reported by studies conducted in similar forest podzol soils (Jassal et al., 2004, 2005; Tang 

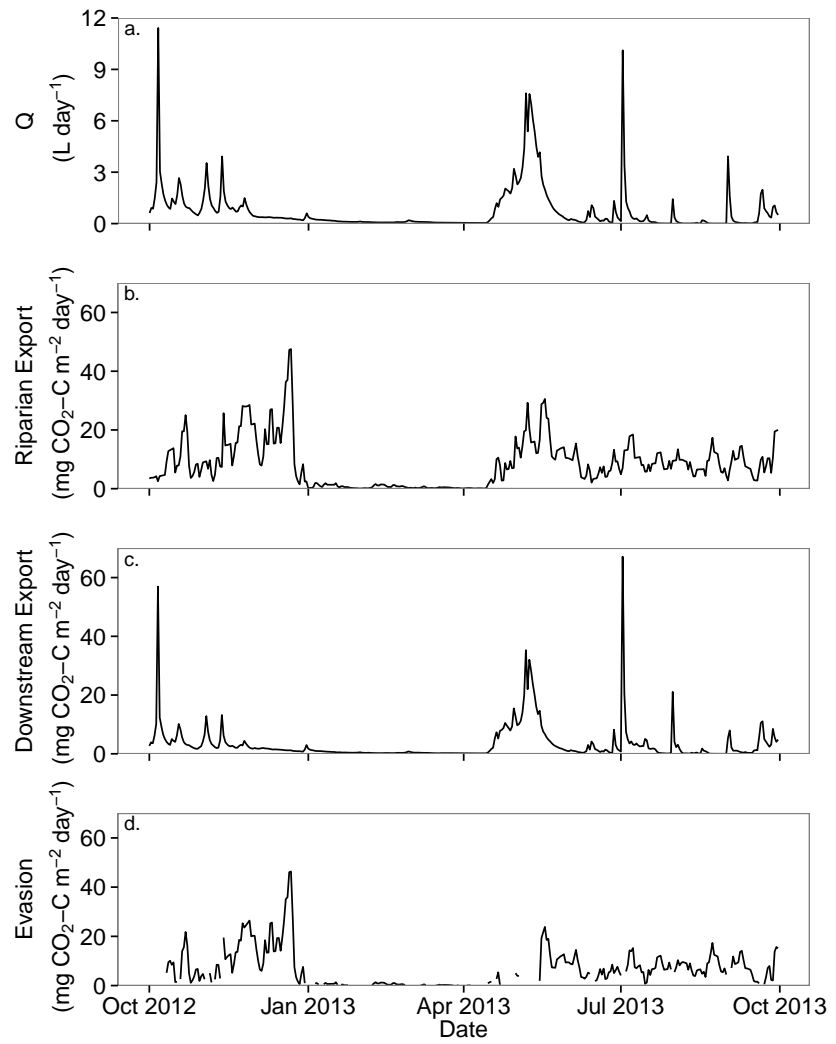

Figure 4. Mean daily (a) discharge $(Q)$, (b) $\mathrm{CO}_{2}$ export from the riparian zone to the stream, (c) downstream lateral $\mathrm{CO}_{2}$ export and (d) vertical $\mathrm{CO}_{2}$ evasion over the hydrological year.

et al., 2003). Mean riparian concentrations at $30-40 \mathrm{~cm}$ depth were similar to those in a Finnish riparian zone at the same depth (14 200-16500 ppmv) (Rasilo et al., 2012) but $\mathrm{CO}_{2}$ concentrations at $60-70 \mathrm{~cm}$ depth were considerably higher (Table 1).

There was considerable temporal variability in $\mathrm{CO}_{2}$ concentrations, especially in the hillslope, corresponding to water table fluctuations (Fig. 2). The $\mathrm{CO}_{2}$ concentrations in the hillslope podzol soils over the measurement period, with peaks of 14100 and 13160 ppmv, both occurred during high water table conditions, as also observed by Rasilo et al. (2012). During the winter months (January-April) when the water table was generally low, $\mathrm{CO}_{2}$ concentrations remained relatively stable at $\sim 2000 \mathrm{ppmv}$ (Fig. 2) suggesting that the vertical exchange of $\mathrm{CO}_{2}$ is greater than the lateral export during these periods (Dyson et al., 2011).

Temporal variability in riparian zone $\mathrm{CO}_{2}$ concentrations was more pronounced at $30-40 \mathrm{~cm}$ depth which can largely be attributed to water table fluctuations (the sensor was below the water table for $59 \%$ of the measurement period). The 60-70 cm sampling depth was below the water table for $97 \%$ of the measurement period with water table variability alone unlikely to explain the observed pattern in riparian $\mathrm{CO}_{2}$ concentrations. $\mathrm{CO}_{2}$ concentration was linked to soil tempera- ture, which had a strong seasonal cycle (Fig. 2) suggesting root respiration and/or organic matter decomposition, driven by changes in soil temperature, provides an additional control on $\mathrm{CO}_{2}$ concentrations. During periods of generally high water tables in the riparian zone, such as during the spring snowmelt event in May, concentrations increased (Fig. 2) again highlighting the importance of water table fluctuations on $\mathrm{CO}_{2}$ concentrations in soils.

Overall, the large temporal variability in porewater $\mathrm{CO}_{2}$ concentration, especially in the hillslope, can largely be attributed to water table fluctuations altering the rate of $\mathrm{CO}_{2}$ mobilisation and vertical diffusion of $\mathrm{CO}_{2}$ stored in soil pore space. This confirms the results of others who measured higher $\mathrm{CO}_{2}$ concentrations during periods of water table fluctuation (Jassal et al., 2005; Rasilo et al., 2012). The importance of the water table for $\mathrm{CO}_{2}$ concentration dynamics suggests that pore water $\mathrm{CO}_{2}$ concentration differences between the hillslope and the riparian zone are strongly influenced by the altered diffusion gradient and surface exchange of $\mathrm{CO}_{2}$ with the atmosphere; the riparian zone had continually higher water tables than the hillslope (Fig. 2). However, despite the importance of water table fluctuations, most of the existing studies involving continuous use of $\mathrm{CO}_{2}$ sensors have been focused predominately above the water table, potentially missing this observation (Jassal et al., 2004, 2005; Tang et al., 2003). This highlights the importance of considering $\mathrm{CO}_{2}$ concentration changes over the full soil profile depth, especially in horizons which experience frequent fluctuations between wet and dry conditions. In this study, $\mathrm{CO}_{2}$ concentrations were only determined at two sampling depths (30-40 and 60-70 cm). In the riparian zone the shallower measurement depth was below the water table $59 \%$ of the time giving a range of measurements under saturated and unsaturated conditions. The deeper measurement point was below the water table $97 \%$ of the time giving concentrations under saturated conditions. These two sampling depths therefore gave a good overall representation of soil conditions, and their respective $\mathrm{CO}_{2}$ concentrations.

\subsection{Hillslope-riparian-stream water and $\mathrm{CO}_{2}$ export}

The total export of water per $\mathrm{m}^{2}$ of hillslope was $230 \mathrm{~mm} \mathrm{yr}^{-1}$ and from the riparian zone $270 \mathrm{~mm} \mathrm{yr}^{-1}$. Both estimates correspond well (proportional to the relative upslope contributing area) to the annual catchment runoff of $265 \mathrm{~mm} \mathrm{yr}^{-1}$. The lateral movement of water along the hillslope-riparian-stream continuum is dependent on a number of assumptions, principally that lateral subsurface flow is the dominant hydrological pathway and that these flow paths are perpendicular to the stream. These assumptions have been validated for the study catchment by the observed planar nature of the water table (Cory et al., 2007) and through stable isotope studies (Laudon et al., 2004; PeraltaTapia et al., 2014). Alternative flow paths, such as overland flow and groundwater recharge are not important at this site 
(Grabs et al., 2012). Downslope lateral water flow occurs in saturated soils, with minimal lateral flow occurring above the water table, in accordance with the transmissivity feedback conceptualisation of subsurface flows in shallow till catchments (Bishop et al., 2011; Rodhe, 1989).

Transmissivity feedback, which has been widely observed in this catchment, is defined as the increase in lateral saturated hydraulic conductivity towards the soil surface, resulting in more lateral flow as water table rises into near surface soil horizons (Bishop et al., 1990, 2004; Laudon et al., 2004). The drier hillslope podzol soils had a greater potential to store water without increasing water table (Seibert et al., 2003), limiting the time in which high water table conditions occurred; mean water position in the hillslope was $-63 \mathrm{~cm}$. Water table only moved into higher lateral hydraulic conductivity horizons during the spring snowmelt event in May when $42 \%$ of annual hillslope $\mathrm{CO}_{2}$ export occurred, emphasising the importance of the spring snowmelt event in this system. The results from this study show that maximum water export occurs where water table position and soil hydrological properties (lateral hydraulic conductivity and soil water content) combine to produce the set of conditions most conducive to water flow, in agreement with the transmissivity feedback principle.

The concept of a riparian chemosphere has been conceptualised by and shown to exist in the catchment studied here (Bishop et al., 2004; Seibert et al., 2009), with the chemistry of water flowing laterally through the catchment determined by soil interactions. The final soil encountered by subsurface waters (in this study the riparian peat soils) will determine the composition of water transported across the terrestrialaquatic interface (Bishop et al., 2004). Over the hydrological year, total $\mathrm{CO}_{2}$ export per $\mathrm{m}^{2}$ of hillslope was $1144 \mathrm{mg} \mathrm{CO}_{2}$ $\mathrm{C} \mathrm{m}^{-2} \mathrm{yr}^{-1}$ with export from the riparian zone estimated at $3008 \mathrm{mg} \mathrm{CO}_{2}-\mathrm{C} \mathrm{m}^{-2} \mathrm{yr}^{-1}$. The organic rich peat soils of the riparian zone therefore represent a significantly greater $\mathrm{CO}_{2}$ export source than the podzol hillslope soils, despite accounting for $<10 \%$ of the catchment area. This can be related to the higher measured $\mathrm{CO}_{2}$ concentrations (Fig. 2). The importance of riparian-stream $\mathrm{CO}_{2}$ export is in agreement with the results for other catchments (Peter et al., 2014; Rasilo et al., 2012) and for total organic carbon in this catchment (Grabs et al., 2012).

Few studies have estimated carbon export across the terrestrial-aquatic interface, especially for $\mathrm{CO}_{2}$. The total annual export of $\mathrm{CO}_{2}$ in this study $\left(3.0 \mathrm{~g} \mathrm{CO}_{2}-\mathrm{C} \mathrm{m}^{-2} \mathrm{yr}^{-1}\right)$ was similar, given the large inter-annual variability, to the estimate for DIC $\left(3.2 \mathrm{~g} \mathrm{DIC} \mathrm{m}^{-2} \mathrm{yr}^{-1}\right)$ produced from spot measurements (Öquist et al., 2009) and the 2.3$6.9 \mathrm{~g} \mathrm{DIC} \mathrm{m}^{-2} \mathrm{yr}^{-1}$ estimated over a longer period (19972009) in the same catchment (Öquist et al., 2014). As expected, $\mathrm{CO}_{2}$ export was lower than in peat dominated catchments in Sweden (3.1-6.0 $\mathrm{g} \mathrm{CO}_{2}-\mathrm{C} \mathrm{m}^{-2} \mathrm{yr}^{-1}$ ) (Nilsson et al., 2008) and Scotland (11.2-15.5 $\mathrm{g} \mathrm{CO}_{2}-\mathrm{C} \mathrm{m}^{-2} \mathrm{yr}^{-1}$ ) (Dinsmore et al., 2010, 2013b).
The results of this study suggest that the riparian zone, and not the wider hillslope, is the dominant source of $\mathrm{CO}_{2}$ entering the stream but the contribution of the riparian zone to water and $\mathrm{CO}_{2}$ transport has been shown to be episodic, resulting in hotspots and hot moments when export is greatest (McClain et al., 2003; Vidon et al., 2010). $\mathrm{CO}_{2}$ export was highest in a narrow band between 30 and $50 \mathrm{~cm}$ depth, which accounted for $71 \%$ of $\mathrm{CO}_{2}$ export. The results from this study suggest that the riparian zone contains two distinct sources of $\mathrm{CO}_{2}$ export; high export rates at $30-50 \mathrm{~cm}$ depth as water table moves into more superficial horizons and a deeper (> $65 \mathrm{~cm}$ depth) continuous but smaller export (Fig. 3). The presence of these two water sources in this catchment has also been shown isotopically (Peralta-Tapia et al., 2014) and indicated by the observed bimodal frequency distributions in stream water $\mathrm{CO}_{2}$ concentrations during storm events (Dinsmore et al., 2013a). Therefore, the riparian export rates of water and $\mathrm{CO}_{2}$ measured here can be used to explain the observed changes in stream water $\mathrm{CO}_{2}$ concentrations. This approach can be used as the catchment chosen for this study is relatively simple in terms of the water flow paths (with water transported laterally through the soil at $<1 \mathrm{~m}$ depth with groundwater and overland flow not significant) and the consistency of the riparian lateral extent down the stream reach. In catchments with more complex hydrology or where the riparian lateral extent is variable, riparian $\mathrm{CO}_{2}$ export alone may not account for all variability in stream water $\mathrm{CO}_{2} \mathrm{dy}-$ namics and additional sources would need to be considered.

Peaks in water and $\mathrm{CO}_{2}$ export occurred in late autumn (October-December) and May. The export of water from the riparian zone was highest during May at $49 \mathrm{mmmonth}^{-1}$ when the spring snowmelt event occurred, accounting for $18 \%$ of the annual water export from the riparian zone. In May, at the onset of spring snowmelt, $\mathrm{CO}_{2}$ concentrations were close to minimum values of 3840 and $14400 \mathrm{ppmv}$ at $30-40$ and $60-70 \mathrm{~cm}$ depths in the riparian zone, resulting in relatively low $\mathrm{CO}_{2}$ export despite large water export at this time. In October-December, despite only moderate water export, $\mathrm{CO}_{2}$ export was high $\left(275-529 \mathrm{mg} \mathrm{CO}_{2}-\right.$ $\mathrm{C} \mathrm{m}^{-2}$ month ${ }^{-1}$ ) (Fig. 3). During these months, $\mathrm{CO}_{2}$ concentrations in the riparian soil were at or close to their maximum values (Fig. 2), coinciding with maximum soil water DOC concentrations in late summer/autumn observed in the catchment (Lyon et al., 2011). This observed pattern of peaks in $\mathrm{CO}_{2}$ export suggests that riparian export is a function of both season and runoff. This highlights the importance of capturing hydrological extremes when quantifying annual estimates of downstream export and evasion of $\mathrm{CO}_{2}$ across catchments and scales.

The lateral export of riparian dissolved $\mathrm{CO}_{2}$ is therefore the main source of stream water $\mathrm{CO}_{2}$, with the amount of $\mathrm{CO}_{2}$ exported related to the depth of water flow through the riparian zone. The riparian export of $\mathrm{CO}_{2}$ can therefore be used as an estimate of the catchment $\mathrm{CO}_{2}$ export to partition the export of $\mathrm{CO}_{2}$ via the aquatic conduit. 


\subsection{Downstream $\mathrm{CO}_{2}$ export and evasion}

Total downstream lateral $\mathrm{CO}_{2}$ export, calculated from the $\mathrm{CO}_{2}$ concentration and discharge at the catchment outlet, over the hydrological year was $1.2 \mathrm{~g} \mathrm{CO}_{2}-\mathrm{C} \mathrm{m}^{-2} \mathrm{yr}^{-1}$. This is within the range $0.9-1.3 \mathrm{~g} \mathrm{CO}_{2}-\mathrm{C} \mathrm{m}^{-2} \mathrm{yr}^{-1}$ of estimates for the same catchment (Öquist et al., 2009) and a peatland catchment in southern Scotland (Dinsmore et al., $2010,2013 b)$. Due to the greater range in discharge (0.02$15.3 \mathrm{~L} \mathrm{~s}^{-1}$ ) than dissolved $\mathrm{CO}_{2}$ concentrations (daily mean $\mathrm{CO}_{2}$ concentration ranged from $1.8-7.2 \mathrm{mg} \mathrm{CO}_{2}-\mathrm{CL}^{-1}$ ); discharge had a greater influence on temporal variability in downstream lateral $\mathrm{CO}_{2}$ export (Fig. 4).

By subtracting downstream lateral $\mathrm{CO}_{2}$ export (1183 $\mathrm{mgCO}_{2}-\mathrm{C} \mathrm{m}^{-2} \mathrm{yr}^{-1}$ ) from the estimate of soil export over the same period $\left(3008 \mathrm{mg} \mathrm{CO}_{2}-\mathrm{C} \mathrm{m}^{-2} \mathrm{yr}^{-1}\right)$, an estimated $1825 \mathrm{mg} \mathrm{CO}_{2}-\mathrm{C} \mathrm{m}^{-2} \mathrm{yr}^{-1}$ was released to the stream but not accounted for by downstream lateral export. Photosynthetic uptake by aquatic plants or in stream respiration is unlikely to be important in this catchment due to the short water residence times (typically $\sim 4.5 \mathrm{~h}$ ) and the low temperatures (Öquist et al., 2009). Hence the remaining $\mathrm{CO}_{2}$ is likely to be evaded from the stream surface. Our evasion estimate from the stream surface $\left(1825 \mathrm{mg} \mathrm{CO}_{2}-\mathrm{C} \mathrm{m}^{-2} \mathrm{yr}^{-1}\right)$ was at the lower end of evasion rates determined from direct point measurements in the same catchment (Wallin et al., 2011). However, evasion accounted for $60 \%$ of export via the aquatic pathway supporting previous findings of the rapid $\mathrm{CO}_{2}$ loss from the stream (Öquist et al., 2009).

Estimating evasion rate based on this approach is dependent on two assumptions: (1) all stream water $\mathrm{CO}_{2}$ is derived from lateral soil inputs from the riparian zone and (2) a short water transport time between the riparian zone and the stream to allow rapid exchange of water and $\mathrm{CO}_{2}$ during events. In headwater systems, in-stream productivity (through biological respiration and photo-degradation of DOC) is limited by the cold temperatures, low $\mathrm{pH}$ and short water residence times (Dawson et al., 2001). Additionally, $\mathrm{CO}_{2}$ evasion from headwater streams has been widely shown to be composed predominately of recently fixed, plant derived $\mathrm{CO}_{2}$ transported from the surrounding soil (Billett et al., 2012; Leith et al., 2014). The transport time for water between the riparian zone and the stream varied with depth from $<1 \mathrm{~h}$ at $<15 \mathrm{~cm}$ depth up to $\sim 25 \mathrm{~h}$ at $>70 \mathrm{~cm}$ depth. The lateral exchange of water and $\mathrm{CO}_{2}$ between the riparian zone and the stream was rapid enough for the approach to be valid at the daily scale that was used in the model. Additionally, the total volume of water exported from the riparian zone $\left(270 \mathrm{~mm} \mathrm{yr}^{-1}\right)$ corresponded well with the annual runoff from the catchment $\left(265 \mathrm{~mm} \mathrm{yr}^{-1}\right)$ suggesting that no other inputs of water are contributing. Riparian $\mathrm{CO}_{2}$ export to the stream is therefore sustaining the lateral downstream export and vertical evasion of $\mathrm{CO}_{2}$.

There was considerable temporal variability in the evasion estimate (Fig. 4) related to variability in $\mathrm{CO}_{2}$ dynamics in both the terrestrial (Fig. 2) and aquatic systems (Fig. 4). During the two largest storm events, in which discharge increased suddenly over a very short time period $(<1$ day), downstream lateral export spiked but without a corresponding increase in soil export. Evasion was therefore not estimated during these periods. This also occurred during the onset of the spring flood. This suggests that during storms there may be a rapid input of overland flow or direct channel water input contributing to discharge without interacting with the soil. The model used to estimate soil $\mathrm{CO}_{2} \mathrm{ex}-$ port did not include overland flow so may be underestimating the total flow of water and $\mathrm{CO}_{2}$ into the stream during storm events. Overland flow has been shown to be a relatively minor flow path within the Västrabäcken catchment (Grabs et al., 2012; Peralta-Tapia et al., 2014). However, during the spring flood, up to $20 \%$ of stream runoff was found to be derived from snowmelt transported via overland flow (Laudon et al., 2004). Thus during the spring snowmelt period, water and $\mathrm{CO}_{2}$ stored within the snowpack may be an additional export source, bypassing the soil profile. In two Finnish catchments, $\mathrm{CO}_{2}$ concentrations in the snow pack of 500-1900 ppmv were recorded (Dyson et al., 2011) with snowmelt estimated to contribute $35-46 \%$ of downstream lateral $\mathrm{CO}_{2}$ export during the spring snowmelt period (Dinsmore et al., 2011). Over the course of the spring snowmelt event in the same Finnish catchments the isotopic signature of evaded $\mathrm{CO}_{2}$ showed a decreasing contribution from recently fixed, plant derived $\mathrm{CO}_{2}$ from near surface soil horizons with a corresponding increase in the atmospheric $\mathrm{CO}_{2}$ component, likely derived from the melting snow pack (Billett et al., 2012). In some headwater catchments, the effects of melt water and overland flow would need to be accounted for in annual estimates of riparian $\mathrm{CO}_{2}$ export.

Although the annual estimate of riparian export and evasion in the study compare well to estimates from discrete measurements (Öquist et al., 2009), the results of this study highlight the importance of high frequency, direct measurements of $\mathrm{CO}_{2}$ concentrations given the high temporal variability in $\mathrm{CO}_{2}$ dynamics in the terrestrial and aquatic systems. Terrestrial processes have been shown to have an important role in determining $\mathrm{CO}_{2}$ export via the aquatic pathway in a wide range of catchments (Abril et al., 2014; Butman and Raymond, 2011; Crawford et al., 2013). The results from this catchment indicate that terrestrial-aquatic export of $\mathrm{CO}_{2}$ was controlled by riparian water table dynamics, highlighting the potential importance of riparian zones in headwater catchments. Changes in climate, especially greater variability in precipitation patterns (IPCC, 2007), have the potential to alter riparian water table dynamics and since carbon export via the aquatic pathway has been shown to be positively correlated with precipitation (Öquist et al., 2014), impact on the export of $\mathrm{CO}_{2}$ to streams and the NECB of boreal headwater catchments. 


\section{Conclusions}

$\mathrm{CO}_{2}$ concentrations were significantly higher in the riparian zone than hillslope soils, which we infer was due to (1) greater production of $\mathrm{CO}_{2}$ in riparian peats compared to the hillslope podzols and (2) higher water table positions limiting the vertical $\mathrm{CO}_{2}$ diffusion and exchange with the atmosphere. The results of this study suggest that the riparian zone, and not the wider hillslope, is the dominant source of $\mathrm{CO}_{2}$ entering the stream with a hotspot for export observed at $30-50 \mathrm{~cm}$ depth (accounting for $71 \%$ of total riparian export). Seasonal variability was high with peaks in export during the spring flood and autumn storm events highlighting the importance of high frequency measurements in this very dynamic system.

Downstream $\mathrm{CO}_{2}$ export (determined from stream water dissolved $\mathrm{CO}_{2}$ concentrations and discharge) was $1.2 \mathrm{~g} \mathrm{CO}_{2}$ $\mathrm{C} \mathrm{m}^{-2} \mathrm{yr}^{-1}$. Subtracting downstream lateral export from riparian input $\left(3.0 \mathrm{~g} \mathrm{CO}_{2}-\mathrm{C} \mathrm{m}^{-2} \mathrm{yr}^{-1}\right)$ gives $1.8 \mathrm{~g} \mathrm{CO}_{2}$ $\mathrm{C} \mathrm{m}^{-2} \mathrm{yr}^{-1}$ which can be attributed to evasion losses (accounting for $60 \%$ of export via the aquatic pathway). The results highlight the importance of terrestrial $\mathrm{CO}_{2}$ export, especially from the riparian zone, for determining catchment aquatic $\mathrm{CO}_{2}$ losses and especially for maintaining the high evasion fluxes from boreal headwater streams.

Acknowledgements. The work was funded by a UK Natural Environment Research Council (NERC) Algorithm PhD studentship (NE/I527996/1) and the Swedish Research Council (2012-3919). We thank all those involved in the Krycklan catchment study, especially Peder Blomkvist and Victor Sjöblom, for all their field assistance.

Edited by: S. Bouillon

\section{References}

Abril, G., Martinez, J.-M., Artigas, L. F., Moreira-Turcq, P., Benedetti, M. F., Vidal, L., Meziane, T., Kim, J.-H., Bernardes, M. C., Savoye, N., Deborde, J., Lima Souza, E., Albéric, P., Landim de Souza, M. F., and Roland, F.: Amazon River carbon dioxide outgassing fuelled by wetlands, Nature, 505, 395-398, doi:10.1038/nature12797, 2014.

Aufdenkampe, A. K., Mayorga, E., Raymond, P. A., Melack, J. M., Doney, S. C., Alin, S. R., Aalto, R. E., and Yoo, K.: Riverine coupling of biogeochemical cycles between land, oceans, and atmosphere, Front. Ecol. Environ., 9, 53-60, doi:10.1890/100014, 2011.

Billett, M., Garnett, M., Dinsmore, K., Dyson, K., Harvey, F., Thomson, A., Piirainen, S., and Kortelainen, P.: Age and source of different forms of carbon released from boreal peatland streams during spring snowmelt in E. Finland, Biogeochemistry, 111, 273-286, doi:10.1007/s10533-011-9645-4, 2012.

Billett, M. F., Palmer, S. M., Hope, D., Deacon, C., StoretonWest, R., Hargreaves, K. J., Flechard, C., and Fowler,
D.: Linking land-atmosphere-stream carbon fluxes in a lowland peatland system, Global Biogeochem. Cy., 18, GB1024, doi:10.1029/2003GB002058, 2004.

Bishop, K., Seibert, J., Köhler, S., and Laudon, H.: Resolving the Double Paradox of rapidly mobilized old water with highly variable responses in runoff chemistry, Hydrol. Process., 18, 185189, doi:10.1002/hyp.5209, 2004.

Bishop, K., Seibert, J., Nyberg, L., and Rodhe, A.: Water storage in a till catchment. II: Implications of transmissivity feedback for flow paths and turnover times, Hydrol. Process., 25, 3950-3959, doi:10.1002/hyp.8355, 2011.

Bishop, K. H., Grip, H., and O'Neill, A.: The origins of acid runoff in a hillslope during storm events, J. Hydrol., 116, 35-61, doi:10.1016/0022-1694(90)90114-D, 1990.

Burt, T. P., Pinay, G., Matheson, F. E., Haycock, N. E., Butturini, A., Clement, J. C., Danielescu, S., Dowrick, D. J., Hefting, M. M., Hillbricht-Ilkowska, A., and Maitre, V.: Water table fluctuations in the riparian zone: comparative results from a pan-European experiment, J. Hydrol., 265, 129-148, doi:10.1016/S0022-1694(02)00102-6, 2002.

Butman, D. and Raymond, P. A.: Significant efflux of carbon dioxide from streams and rivers in the United States, Nat. Geosci., 4, 839-842, doi:10.1038/ngeo1294, 2011.

Buttle, J., Dillon, P., and Eerkes, G.: Hydrologic coupling of slopes, riparian zones and streams: an example from the Canadian Shield, J. Hydrol., 287, 161-177, doi:10.1016/j.jhydrol.2003.09.022, 2004.

Cory, N., Laudon, H., Köhler, S., Seibert, J., and Bishop, K.: Evolution of soil solution aluminum during transport along a forested boreal hillslope, J. Geophys. Res.-Biogeo., 112, G03014, doi:10.1029/2006JG000387, 2007.

Crawford, J. T., Striegl, R. G., Wickland, K. P., Dornblaser, M. M., and Stanley, E. H.: Emissions of carbon dioxide and methane from a headwater stream network of interior Alaska, J. Geophys. Res.-Biogeo., 118, 482-494, doi:10.1002/jgrg.20034, 2013.

Dawson, J. J. C., Billett, M. F., and Hope, D.: Diurnal variations in the carbon chemistry of two acidic peatland streams in north-east Scotland, Freshwater Biol., 46, 1309-1322, doi:10.1046/j.13652427.2001.00751.x, 2001.

Dinsmore, K. J. and Billett, M. F.: Continuous measurement and modeling of $\mathrm{CO}_{2}$ losses from a peatland stream during stormflow events, Water Resour. Res., 44, W12417, doi:10.1029/2008WR007284, 2008.

Dinsmore, K. J., Billett, M. F., and Moore, T. R.: Transfer of carbon dioxide and methane through the soil-water-atmosphere system at Mer Bleue peatland, Canada, Hydrol. Process., 23, 330-341, doi:10.1002/hyp.7158, 2009.

Dinsmore, K. J., Billett, M. F., Skiba, U. M., Rees, R. M., Drewer, J., and Helfter, C.: Role of the aquatic pathway in the carbon and greenhouse gas budgets of a peatland catchment, Glob. Change Biol., 16, 2750-2762, doi:10.1111/j.1365-2486.2009.02119.x, 2010.

Dinsmore, K. J., Billett, M. F., Dyson, K. E., Harvey, F., Thomson, A. M., Piirainen, S., and Kortelainen, P.: Stream water hydrochemistry as an indicator of carbon flow paths in Finnish peatland catchments during a spring snowmelt event, Sci. Total Environ., 409, 4858-4867, doi:10.1016/j.scitotenv.2011.07.063, 2011.

Dinsmore, K. J., Wallin, M. B., Johnson, M. S., Billett, M. F., Bishop, K., Pumpanen, J., and Ojala, A.: Contrasting $\mathrm{CO}_{2}$ con- 
centration discharge dynamics in headwater streams: A multicatchment comparison, J. Geophys. Res.-Biogeo., 118, 1-17, doi:10.1002/jgrg.20047, 2013a.

Dinsmore, K. J., Billett, M. F., and Dyson, K. E.: Temperature and precipitation drive temporal variability in aquatic carbon and GHG concentrations and fluxes in a peatland catchment, Glob. Change Biol., 19, 2133-2148, doi:10.1111/gcb.12209, 2013b.

Dunn, A. L., Barford, C. C., Wofsy, S. C., Goulden, M. L., and Daube, B. C.: A long-term record of carbon exchange in a boreal black spruce forest: means, responses to interannual variability, and decadal trends, Glob. Change Biol., 13, 577-590, doi:10.1111/j.1365-2486.2006.01221.x, 2007.

Dyson, K., Billett, M., Dinsmore, K., Harvey, F., Thomson, A., Piirainen, S., and Kortelainen, P.: Release of aquatic carbon from two peatland catchments in E. Finland during the spring snowmelt period, Biogeochemistry, 103, 125-142, doi:10.1007/s10533-010-9452-3, 2011.

Garnett, M. H., Dinsmore, K. J., and Billett, M. F.: Annual variability in the radiocarbon age and source of dissolved $\mathrm{CO}_{2}$ in a peatland stream, Sci. Total Environ., 427-428, 277-285, doi:10.1016/j.scitotenv.2012.03.087, 2012.

Grabs, T., Bishop, K., Laudon, H., Lyon, S. W., and Seibert, J.: Riparian zone hydrology and soil water total organic carbon (TOC): implications for spatial variability and upscaling of lateral riparian TOC exports, Biogeosciences, 9, 3901-3916, doi:10.5194/bg-9-3901-2012, 2012.

Haei, M., Öquist, M. G., Buffam, I., Ågren, A., Blomkvist, P., Bishop, K., Ottosson Löfvenius, M., and Laudon, H.: Cold winter soils enhance dissolved organic carbon concentrations in soil and stream water, Geophys. Res. Lett., 37, L08501, doi:10.1029/2010GL042821, 2010.

Hope, D., Palmer, S. M., Billett, M. F., and Dawson, J. J. C.: Carbon dioxide and methane evasion from a temperate peatland stream, Limnol. Oceanogr., 46, 847-857, doi:10.4319/lo.2001.46.4.0847, 2001.

Hope, D., Palmer, S. M., Billett, M. F., and Dawson, J. J. C.: Variations in dissolved $\mathrm{CO}_{2}$ and $\mathrm{CH}_{4}$ in a first-order stream and catchment: an investigation of soil-stream linkages, Hydrol. Process., 18, 3255-3275, doi:10.1002/hyp.5657, 2004.

Humborg, C., Morth, C.-M., Sundbom, M., Borg, H., Blenckner, T., Giesler, R., and Ittekkot, V.: $\mathrm{CO}_{2}$ supersaturation along the aquatic conduit in Swedish watersheds as constrained by terrestrial respiration, aquatic respiration and weathering, Glob. Change Biol., 16, 1966-1978, doi:10.1111/j.13652486.2009.02092.x, 2010.

IPCC: Climate Change 2007 - The Physical Science Basis: Working Group I Contribution to the Fourth Assessment Report of the IPCC, Intergovernmental Panel on Climate Change, Geneva, Switzerland, 2007.

Jassal, R., Black, T., Drewitt, G., Novak, M., Gaumont-Guay, D., and Nesic, Z.: A model of the production and transport of $\mathrm{CO}_{2}$ in soil: predicting soil $\mathrm{CO}_{2}$ concentrations and $\mathrm{CO}_{2}$ efflux from a forest floor, Agr. Forest Meteorol., 124, 219-236, doi:10.1016/j.agrformet.2004.01.013, 2004.

Jassal, R., Black, A., Novak, M., Morgenstern, K., Nesic, Z., and Gaumont-Guay, D.: Relationship between soil $\mathrm{CO}_{2}$ concentrations and forest-floor $\mathrm{CO}_{2}$ effluxes, Agr. Forest Meteorol., 130, 176-192, doi:10.1016/j.agrformet.2005.03.005, 2005.
Jassal, R. S., Black, T. A., Novak, M. D., Gaumont-Guay, D., and Nesic, Z.: Effect of soil water stress on soil respiration and its temperature sensitivity in an 18-year-old temperate Douglas-fir stand, Glob. Change Biol., 14, 1305-1318, doi:10.1111/j.13652486.2008.01573.x, 2008.

Johnson, M. S., Lehmann, J., Couto, E. G., Filho, J. P. N., and Riha, S. J.: DOC and DIC in flowpaths of Amazonian headwater catchments with hydrologically contrasting soils, Biogeochemistry, 81, 45-57, doi:10.1007/s10533-006-9029-3, 2006.

Johnson, M. S., Billett, M. F., Dinsmore, K. J., Wallin, M., Dyson, K. E., and Jassal, R. S.: Direct and continuous measurement of dissolved carbon dioxide in freshwater aquatic systems: method and applications, Ecohydrology, 3, 68-78, doi:10.1002/eco.95, 2010.

Kling, G. W., Kipphut, G. W., and Miller, M. C.: Arctic lakes and streams as gas conduits to the atmosphere: Implications for tundra carbon budgets, Science, 251, 298, 1991.

Koehler, A.-K., Sottocornola, M., and Kiely, G.: How strong is the current carbon sequestration of an Atlantic blanket bog?, Glob. Change Biol., 17, 309-319, doi:10.1111/j.13652486.2010.02180.x, 2011.

Laudon, H., Seibert, J., Köhler, S., and Bishop, K.: Hydrological flow paths during snowmelt: Congruence between hydrometric measurements and oxygen 18 in meltwater, soil water, and runoff, Water Resour. Res., 40, W03102, doi:10.1029/2003WR002455, 2004.

Laudon, H., Berggren, M., Agren, A., Buffam, I., Bishop, K., Grabs, T., Jansson, M., and Köhler, S.: Patterns and dynamics of dissolved organic carbon (DOC) in boreal streams: The role of processes, connectivity, and scaling, Ecosystems, 14, 880-893, doi:10.1007/s10021-011-9452-8, 2011.

Laudon, H., Taberman, I., Ågren, A., Futter, M., OttossonLöfvenius, M., and Bishop, K.: The Krycklan Catchment Study - A flagship infrastructure for hydrology, biogeochemistry, and climate research in the boreal landscape, Water Resour. Res., 49, 7154-7158, doi:10.1002/wrcr.20520, 2013.

Leith, F. I., Garnett, M. H., Dinsmore, K. J., Billett, M. F., and Heal, K. V.: Source and age of dissolved and gaseous carbon in a peatland-riparian-stream continuum: a dual isotope $\left({ }^{14} \mathrm{C}\right.$ and $\left.\delta^{13} \mathrm{C}\right)$ analysis, Biogeochemistry, 119, 415-433, doi:10.1007/s10533-014-9977-y, 2014.

Luke, S. H., Luckai, N. J., Burke, J. M., and Prepas, E. E.: Riparian areas in the Canadian boreal forest and linkages with water quality in streams, Environ. Rev., 15, 79-97, doi:10.1139/A07-001, 2007.

Lyon, S. W., Grabs, T., Laudon, H., Bishop, K. H., and Seibert, J.: Variability of groundwater levels and total organic carbon in the riparian zone of a boreal catchment, J. Geophys. Res.-Biogeo., 116, G01020, doi:10.1029/2010JG001452, 2011.

McClain, M. E., Boyer, E. W., Dent, C. L., Gergel, S. E., Grimm, N. B., Groffman, P. M., Hart, S. C., Harvey, J. W., Johnston, C. A., Mayorga, E., McDowell, W. H., and Pinay, G.: Biogeochemical hot spots and hot moments at the interface of terrestrial and aquatic ecosystems, Ecosystems, 6, 301-312, doi:10.1007/s10021-003-0161-9, 2003.

Naiman, R. J. and Décamps, H.: The ecology of interfaces: Riparian zones, Annu. Rev. Ecol. Syst., 28, 621-658, doi:10.1146/annurev.ecolsys.28.1.621, 1997. 
Nilsson, M., Sagerfors, J., Buffam, I., Laudon, H., Eriksson, T., Grelle, A., Klemedtsson, L., Weslien, P., and Lindroth, A.: Contemporary carbon accumulation in a boreal oligotrophic minerogenic mire: a significant sink after accounting for all Cfluxes, Glob. Change Biol., 14, 2317-2332, doi:10.1111/j.13652486.2008.01654.x, 2008.

Nyberg, L., Stähli, M., Mellander, P.-E., and Bishop, K. H.: Soil frost effects on soil water and runoff dynamics along a boreal forest transect: 1. Field investigations, Hydrol. Process., 15, 909926, doi:10.1002/hyp.256, 2001.

Olefeldt, D., Roulet, N. T., Bergeron, O., Crill, P., Bäckstrand, K., and Christensen, T. R.: Net carbon accumulation of a high-latitude permafrost palsa mire similar to permafrost-free peatlands, Geophys. Res. Lett., 39, L03501, doi:10.1029/2011GL050355, 2012.

Öquist, M. G., Wallin, M., Seibert, J., Bishop, K., and Laudon, H.: Dissolved inorganic carbon export across the soil/stream interface and its fate in a boreal headwater stream, Environ. Sci. Technol. Lett., 43, 7364-7369, doi:10.1021/es900416h, 2009.

Öquist, M. G., Bishop, K., Grelle, A., Klemedtsson, L., Köhler, S. J., Laudon, H., Lindroth, A., Ottosson Löfvenius, M., Wallin, M. B., and Nilsson, M. B.: The full annual carbon balance of boreal forests is highly sensitive to precipitation, Environ. Sci. Technol., 1, 315-319, doi:10.1021/ez500169j, 2014.

Peralta-Tapia, A., Sponseller, R. A., Tetzlaff, D., Soulsby, C., and Laudon, H.: Connecting precipitation inputs and soil flow pathways to stream water in contrasting boreal catchments, Hydrol. Process., doi:10.1002/hyp.10300, 2014.

Peter, H., Singer, G. A., Preiler, C., Chifflard, P., Steniczka, G., and Battin, T. J.: Scales and drivers of temporal $\mathrm{pCO}_{2}$ dynamics in an Alpine stream, J. Geophys. Res.-Biogeo., 119, 1078-1091, doi:10.1002/2013JG002552, 2014.

Pregitzer, K. S. and Euskirchen, E. S.: Carbon cycling and storage in world forests: biome patterns related to forest age, Glob. Change Biol., 10, 2052-2077, doi:10.1111/j.1365-2486.2004.00866.x, 2004.

Rasilo, T., Ojala, A., Huotari, J., and Pumpanen, J.: Rain induced changes in carbon dioxide concentrations in the soil-lake-brook continuum of a boreal forested catchment, Vadose Zone J., 11, doi:10.2136/vzj2011.0039, 2012.

Raymond, P. A., Hartmann, J., Lauerwald, R., Sobek, S., McDonald, C., Hoover, M., Butman, D., Striegl, R., Mayorga, E., Humborg, C., Kortelainen, P., Dürr, H., Meybeck, M., Ciais, P., and Guth, P.: Global carbon dioxide emissions from inland waters, Nature, 503, 355-359, doi:10.1038/nature12760, 2013.

Rodhe, A.: On the generation of stream runoff in till soils, Nord. Hydrol., 20, 1-8, 1989.

Roulet, N. T., Lafleur, P. M., Richard, P. J. H., Moore, T. R., Humphreys, E. R., and Bubier, J.: Contemporary carbon balance and late Holocene carbon accumulation in a northern peatland, Glob. Change Biol., 13, 397-411, doi:10.1111/j.13652486.2006.01292.x, 2007.
Seibert, J., Bishop, K., Rodhe, A., and McDonnell, J. J.: Groundwater dynamics along a hillslope: A test of the steady state hypothesis, Water Resour. Res., 39, WR001404, doi:10.1029/2002WR001404, 2003.

Seibert, J., Grabs, T., Köhler, S., Laudon, H., Winterdahl, M., and Bishop, K.: Linking soil- and stream-water chemistry based on a Riparian Flow-Concentration Integration Model, Hydrol. Earth Syst. Sci., 13, 2287-2297, doi:10.5194/hess-13-22872009, 2009.

Šimůnek, J. and Suarez, D. L.: Modeling of carbon dioxide transport and production in soil: 1 . Model development, Water Resour. Res., 29, 487-497, doi:10.1029/92WR02225, 1993.

Stähli, M., Nyberg, L., Mellander, P.-E., Jansson, P.-E., and Bishop, K. H.: Soil frost effects on soil water and runoff dynamics along a boreal transect: 2. Simulations, Hydrol. Process., 15, 927-941, doi:10.1002/hyp.232, 2001.

Stieglitz, M., Shaman, J., McNamara, J., Engel, V., Shanley, J., and Kling, G. W.: An approach to understanding hydrologic connectivity on the hillslope and the implications for nutrient transport, Global Biogeochem. Cy., 17, 1105, doi:10.1029/2003GB002041, 2003.

Tang, J., Baldocchi, D. D., Qi, Y., and Xu, L.: Assessing soil $\mathrm{CO}_{2}$ efflux using continuous measurements of $\mathrm{CO}_{2}$ profiles in soils with small solid-state sensors, Agr. Forest Meteorol., 118, 207220, doi:10.1016/S0168-1923(03)00112-6, 2003.

Vidon, P., Allan, C., Burns, D., Duval, T. P., Gurwick, N., Inamdar, S., Lowrance, R., Okay, J., Scott, D., and Sebestyen, S.: Hot spots and hot moments in riparian zones: Potential for improved water quality management, J. Am. Water Resour. As., 46, 278-298, doi:10.1111/j.1752-1688.2010.00420.x, 2010.

Wallin, M., Buffam, I., Öquist, M., Laudon, H., and Bishop, K.: Temporal and spatial variability of dissolved inorganic carbon in a boreal stream network: Concentrations and downstream fluxes, J. Geophys. Res.-Biogeo., 115, G02014, doi:10.1029/2009JG001100, 2010.

Wallin, M. B., Öquist, M. G., Buffam, I., Billett, M. F., Nisell, J., and Bishop, K. H.: Spatiotemporal variability of the gas transfer coefficient $\left(\mathrm{KCO}_{2}\right)$ in boreal streams: Implications for large scale estimates of $\mathrm{CO}_{2}$ evasion, Global Biogeochem. Cy., 25, GB3025, doi:10.1029/2010GB003975, 2011.

Wallin, M. B., Grabs, T., Buffam, I., Laudon, H., Agren, A., Öquist, M. G., and Bishop, K.: Evasion of $\mathrm{CO}_{2}$ from streams: The dominant component of the carbon export through the aquatic conduit in a boreal landscape, Glob. Change Biol., 19, 785-797, doi:10.1111/gcb.12083, 2013.

Wallin, M. B., Löfgren, S., Erlandsson, M., and Bishop, K.: Representative regional sampling of carbon dioxide and methane concentrations in hemiboreal headwater streams reveal underestimates in less systematic approaches, Global Biogeochem. Cy., 28, 465-479, doi:10.1002/2013GB004715, 2014. 